\title{
Evaluation of Newly Developed Chemical Castration Method: Changes in Hormone Gene Expression of Hypothalamic-Pituitary Axis
}

\author{
Byung Kuk Kwak and `Sung-Ho Lee \\ Department of Life Science, Sangmyung University, Seoul 03016, Korea
}

\begin{abstract}
Surgical castration (also known as orchidectomy, ORX) has been frequently performed to avoid uncontrolled breeding. However, it has some serious disadvantages. Several laboratories have developed chemical castration methods, using bilateral intratesticular injection (BITI) of simple chemical solutions. The present study was undertaken to compare the effects of ORX and of hypertonic saline BITI on the androgen-sensitive tissues such as pituitary and hypothalamus. Serum testosterone (T) levels of ORX animals and hypertonic saline BITI animals (SAL) after 4 weeks of the manipulations exhibited significantly drops as compared with the levels of intact animals (Intact:ORX:SAL $=7.74 \pm$ 1.31:1.34 $\pm 0.19: 1.28 \pm 0.18 \mathrm{ng} / \mathrm{ml}, p<0.001)$. Both ORX and BITI method induced similar stimulatory effects on the pituitary gonadotropin subunits and hypothalamic KiSS-1 gene expressions. In contrast, the effects of ORX and hypertonic saline BITI on hypothalamic GnRH gene expression were different from these gene expressions, shown an inverse relationship between the two groups (Intact:ORX:SAL $=1: 0.45 \pm 0.06: 1: 2.07 \pm 0.41: 1.51 \pm 0.37$ AU; ORX, $p<0.001$; SAL, $p<$ 0.05). In conclusion, we provided evidence that hypertonic saline BITI method has equivalent efficacy of $\mathrm{T}$ depletion to surgical castration in rats. The present study suggests the hypertonic saline BITI could be a promising substitute to conventional surgical castration.
\end{abstract}

Key words : Orchidectomy (ORX), Chemical castration. Hypertonic saline, bilateral Intratesticular injection(BITI), Rat

\section{INTRODUCTION}

Castration can be scientifically defined as extirpation or suppression of testicular function, and can be classified as surgical or chemical (Neto et al., 2014). Setting aside human applications, surgical castration (also known as orchidectomy, ORX) has been frequently performed to avoid uncontrolled breeding of domestic and/or companion animals and to elucidate the androgen-related issues in biomedical researches. Although the ORX method guarantees the perfect sterilization and sufficient testosterone (T) deprivation, it also has several disadvantages such as requirement of anesthesia, unwanted bleeding and infections (Jana \& Samanta, 2006). Therefore substantial number of studies has been conducted to develop chemical castration method for a better alternative to the surgical procedure.

In general, chemical castration uses pharmaceutical drugs such as anti-androgens, steroidogenesis inhibitors and $\mathrm{GnRH}$ analogs (Attar et al., 2009). These drugs were chosen based on the strong backgrounds in endocrinology (i.e., hypotha-

\footnotetext{
Manuscript received September 17, 2017, Received in revised form September 20, 2017, Accepted September 22, 2017

$\dagger$ Corresponding Author : Sung-Ho Lee, Ph.D., Department of Life Science, Sangmyung University, Hongjmoon-2 gil 20, Jongrho-Gu, Seoul 03016, Republic of Korea. Tel: +82-2-2287-5139, Fax: +82-2-2287-0070, E-mail: shlee@smu.ac.kr

This is an Open Access article distributed under the terms of the Creative Commons Attribution Non-Commercial License (http:// creativecommons.org/licenses/by-nc/3.0) which permits unrestricted non-commercial use, distribution, and reproduction in any medium, provided the original work is properly cited.
} 
lamus-pituitary-testis hormonal axis), but they also have some drawbacks such as high cost, side effects (i.e., bone loss) and poor long-term efficacy (Costantino et al., 2014). Vaccines against GnRH have been reported to suppress reproduction in dogs (Jung et al., 2005), but these approaches are unable to provide permanent sterility (Rhodes, 2017).

Over the last few decades, several laboratories have developed more reliable chemical castration methods, using bilateral intratesticular injection (BITI) of simple chemical solutions such as glycerol (Wiebe \& Barr, 1984), lactic acid (Fordyce et al., 1989), calcium chloride $\left(\mathrm{CaCl}_{2}\right.$; Jana \& Samanta, 2007; Jana et al., 2002), zinc gluconate (Oliveira et al., 2012), and hypertonic saline $(20 \% \mathrm{NaCl}$; Emir et al., 2008; Emir et al., 2011; Kwak \& Lee, 2013). However, the main goal of the studies was an effective sterilization of non-experimental animals for birth control. Therefore the 'androgen-depleting' potential of the BITI method which may replace ORX procedure in the basic researches has not been examined at all. Indeed, rodent model of androgen deprivation by ORX has been exclusively used in numerous biomedical studies to understand the exact nature of androgen actions on the development, differentiation and physiology of target tissues (Smith et al.,2005; Durán-Pastén et al., 2013).

We hypothesized that the chemical castration by hypertonic saline BITI might have same or equivalent efficacy to surgical castration, so both methods might induce similar responses in the androgen-sensitive tissues. In the previous study, we demonstrated that the hypertonic saline BITI caused the very similar biochemical changes (i.e. genomic DNA degradation patterns and gel electrophoretic protein patterns) in the accessory sex organs as shown in the ORX rats (Kwak \& Lee, 2013). Present study was undertaken, for further evaluation at transcriptional level, to compare the effects of both ORX and hypertonic saline BITI on changes in hormone gene expressions of hypothalamus and pituitary.

\section{MATERIALS \& METHODS}

\section{Animals}

Male Sprague-Dawley rats (5 months old) were obtained from Han-Lim Animal (Gyunggi-do, Korea) and acclimated 1 week in our animal facility under conditions of 12-h light/dark cycle (lights on at 07:00 h) and constant temperature of $22 \pm 1{ }^{\circ} \mathrm{C}$. Animal care and experimental procedures were approved by the Institutional Animal care and the use committee at the Sangmyung University (R-1301) in accordance with guidelines established by the Korea Food and Drug Administration.

Rats were randomly divided into three groups including intact group (Intact), ORX group (ORX) and hypertonic saline BITI group (SAL). Sterilized 20\% saline was directly injected into the animals (750 $\mu \mathrm{L}$ per testis) using $1 \mathrm{~mL}$ syringes. Bilateral ORX was performed at the same day of the saline injection. All rats were sacrificed at 4 weeks after the ORX or saline injection. The serum was collected for T ELISA, and the tissues were used for total RNA extraction.

\section{T ELISA}

Serum $\mathrm{T}$ levels were measured by a competitive ELISA kit according to manufacturer's instructions (ab108666; Abcam, USA). The assay sensitivity was $0.07 \mathrm{ng} / \mathrm{mL}$, and the detection range was $0.2-16 \mathrm{ng} / \mathrm{mL}$.

\section{Total RNA extraction and reverse transcription} polymerase chain reaction (RT-PCR)

Total RNAs were isolated from tissue samples using the single-step, acid guanidinum thiocyanate-phenol-chloroform extraction method. Total RNAs were used in RT-PCR reactions carried out with Maxime ${ }^{\mathrm{TM}}$ RT PreMix (InTron, Korea) and Accupower PCR Premix (GeneAll, Korea) according to the manufacturer's instructions. Sequences of the primers and the specific PCR conditions used in this 
study are listed in Tables 1 and 2, respectively. The reaction products were analyzed by gel electrophoresis in $1.5 \%$ agarose gel $(75 \mathrm{~V}, 65 \mathrm{~min})$ and visualized by ethidium bromide staining. The band intensities were measured using the image analysis system (ImagerIII-1D main software, Bioneer, Korea). Glyceraldehydes-3-phosphate dehydrogenase (GAPDH) PCR was used as reference standard for normalization of quantitative RT-PCRs in the present study.

\section{Statistical analysis}

All values are expressed as the means $( \pm$ S.E. $)$ and differences were analyzed by Student's $t$-test. $P$ values less than 0.05 were considered significant. The IBM PC programs INSTAT and PRISM 4.01 (GraphPad, USA) were used to calculate and plot the results.
Table 2. Specific conditions of PCRs used in this study.

\begin{tabular}{|c|c|c|}
\hline Gene & $\begin{array}{c}\text { Temperature } \& \text { time } \\
\text { denature / annealing / extension }\end{array}$ & $\begin{array}{l}\text { Number } \\
\text { of cycle }\end{array}$ \\
\hline $\operatorname{Cg} \alpha$ & $\begin{array}{l}94^{\circ} \mathrm{C}, 30 \mathrm{sec} / 60^{\circ} \mathrm{C}, \\
40 \mathrm{sec} / 72^{\circ} \mathrm{C}, 40 \mathrm{sec}\end{array}$ & 27 \\
\hline LH- $\beta$ & $\begin{array}{l}94^{\circ} \mathrm{C}, 30 \mathrm{sec} / 68^{\circ} \mathrm{C}, \\
40 \sec / 72^{\circ} \mathrm{C}, 40 \mathrm{sec}\end{array}$ & 28 \\
\hline FSH- $\beta$ & $\begin{array}{l}94^{\circ} \mathrm{C}, 30 \sec / 68^{\circ} \mathrm{C} \\
40 \mathrm{sec} / 72^{\circ} \mathrm{C}, 40 \mathrm{sec}\end{array}$ & 29 \\
\hline KiSS-1 & $\begin{array}{l}94^{\circ} \mathrm{C}, 30 \mathrm{sec} / 68^{\circ} \mathrm{C}, \\
40 \mathrm{sec} / 72^{\circ} \mathrm{C}, 40 \mathrm{sec}\end{array}$ & 35 \\
\hline GnRH & $\begin{array}{l}94^{\circ} \mathrm{C}, 30 \mathrm{sec} / 64^{\circ} \mathrm{C}, \\
40 \sec / 72^{\circ} \mathrm{C}, 40 \mathrm{sec}\end{array}$ & 35 \\
\hline GAPDH & $\begin{array}{l}94^{\circ} \mathrm{C}, 30 \mathrm{sec} / 62^{\circ} \mathrm{C}, \\
40 \mathrm{sec} / 72^{\circ} \mathrm{C}, 40 \mathrm{sec}\end{array}$ & 28 \\
\hline
\end{tabular}

Table 1. Sequences of the primers used in this study

\begin{tabular}{|c|c|c|c|}
\hline Gene & Accession number & Nucleotide sequences & Length of PCR product \\
\hline \multirow{2}{*}{$\operatorname{Cg} \alpha$} & \multirow{2}{*}{ BC_063160 } & F 5'-ATA CTT CTC CAA GCT GGG TG & \multirow{2}{*}{294 bp } \\
\hline & & R 5'-CGA CAC TCA GTG CCA TCG CA & \\
\hline \multirow{2}{*}{ LH- $\beta$} & \multirow{2}{*}{ NM_012858 } & F 5'-AGA TGG ACA GCC TTG TGA CC & \multirow{2}{*}{$425 \mathrm{bp}$} \\
\hline & & R 5'-AGG ACT GCT AGC AGC ACT GT & \\
\hline \multirow{2}{*}{ FSH- $\beta$} & \multirow{2}{*}{ BC_168724 } & F 5'-AAC TGC ACA GGA CAT AGC TG & \multirow{2}{*}{344 bp } \\
\hline & & R 5'-ACA GTG GCA TTC AGT GGC TA & \\
\hline \multirow{2}{*}{ KiSS-1 } & \multirow{2}{*}{ NM_181692 } & F 5'-ATC TCG CTG GCT TCT TGG CA & \multirow{2}{*}{319 bp } \\
\hline & & R 5'- GAC ATG TCC TTC TCG CGC TG & \\
\hline \multirow{2}{*}{ GnRH } & \multirow{2}{*}{ NM_012767 } & F 5'-TCC AGC CAG CAC TGG TCC TA & \multirow{2}{*}{$170 \mathrm{bp}$} \\
\hline & & R 5'-GCT CCT CGC AGA TCC CTA AG & \\
\hline \multirow{2}{*}{ GAPDH } & \multirow{2}{*}{ NM_017008 } & F 5'-CCA TCA CCA TCT TCC AGG AG & \multirow{2}{*}{$557 \mathrm{bp}$} \\
\hline & & R 5'-CCT GCT TCA CCA CCT TCT TG & \\
\hline
\end{tabular}

F, forward; R, reverse.

The directions of sequences are all 5' to 3'. 


\section{RESULTS}

\section{Levels of serum $T$ in intact, Post-ORX and sa-} line-treated animals

Fig. 1 shown that the serum T levels of ORX rats after 4 weeks of surgery exhibited a significantly drop $(1.34 \pm 0.19$ $\mathrm{ng} / \mathrm{ml}, p<0.001)$ as compared with the levels of intact animals $(7.74 \pm 1.31 \mathrm{ng} / \mathrm{mL})$. Similarly serum $\mathrm{T}$ levels of hypertonic saline BITI animals (SAL) shown significant decrease $(1.28 \pm 0.18 \mathrm{ng} / \mathrm{mL}, p<0.001)$ as compared with intact animal levels. There was no statistical difference between the T levels of ORX group and SAL group animals.

\section{Changes in pituitary hormone gene expressions}

To elucidate whether the hypertonic saline BITI method possesses equivalent potential with ORX method on the target gene expression at transcription level, we performed

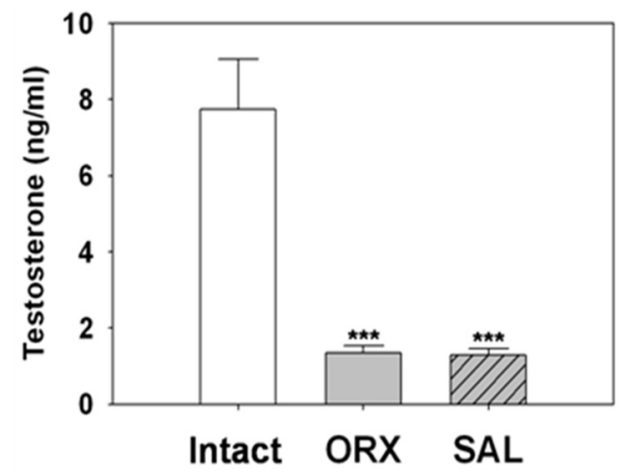

Fig. 1. Serum concentrations of $T$ in intact, ORX or hypertonic saline (SAL) injection groups. Four weeks after surgical castration or hypertonic saline BITI, animals were sacrificed, then sera were collected. Serum $\mathrm{T}$ levels (in $30 \mathrm{uL}$ ) were measured by a competitive ELISA kit according to manufacturer's instructions (Abcam, USA). The bar indicates the mean value ( \pm S.E.) of the repeated experiment $(n=6-8)$. Statistical differences were analyzed by Student's $t$ test. *, Significantly different from the intact group, $p<0.05$. ${ }^{* *}$, Significantly different from the intact group, $p<0.01 . * * *$, Significantly different from the intact group, $p<0.001$.
RT-PCRs using the pituitary total RNA samples. In general, both ORX and BITI method induced similar stimulatory effects on the pituitary gonadotropin gene expressions (Fig. $2 \mathrm{~A}, \mathrm{~B}, \mathrm{C})$. Four weeks after castration, the mRNA level of gonadotropin subunit alpha $(\operatorname{Cg} \alpha)$ was significantly increased (1:1.99 $\pm 0.22 \mathrm{AU}, p<0.01)$. Likewise, the $\mathrm{Cg} \alpha$ mRNA level of hypertonic saline BITI group was significantly increased $(1: 2.08 \pm 0.18 \mathrm{AU}, p<0.001)$. We found no difference between the levels of ORX and BITI groups. The levels of LH- $\beta$ mRNAs were also significantly increased in both ORX group and hypertonic saline BITII group (1ntact: ORX:SAL $=1: 5.04 \pm 1.15: 4.76 \pm 1.14$ AU, $p<0.01)$. The levels of FSH- $\beta$ transcript also shown similar stimulatory results in ORX group and hypertonic saline BITI group (1ntact:ORX:SAL = 1:2.84 $\pm 0.53: 2.76 \pm 0.54 \mathrm{AU}, p<0.01$ ).

\section{Changes in hypothalamic hormone gene ex-} pressions

The effects of two castration methods on hypothalamic gene expressions varied depending on the genes (Fig. 3). The Kiss-1 mRNA level was significantly increased in ORX group (1:4.91 $\pm 0,58$ AU, $p<0.001$, Fig. $3 A$ ). Similarly, the Kiss-1 mRNA level was significantly increased in hypertonic saline bITI group (1:4.20 $\pm 0.91 \mathrm{AU}, p<0.05)$. There was no difference between the levels of ORX and BITI groups. The GnRH mRNA level of ORX group was significantly higher than that of intact group (1:1.64 \pm 0.19 $\mathrm{AU}, p<0.01$, Fig. 3B). Interestingly, the GnRH mRNA level of BITI group was significantly lower than that of intact group (1:0.45 $\pm 0.06 \mathrm{AU}, p<0.001)$, showing inverse relationship between the two groups.

\section{DISCUSSION}

The present study aimed to investigate whether the chemical castration with simple salt solution can be a substitute for surgical castration in the preparation of androgendeprivation animal model. In particular, we compared the 

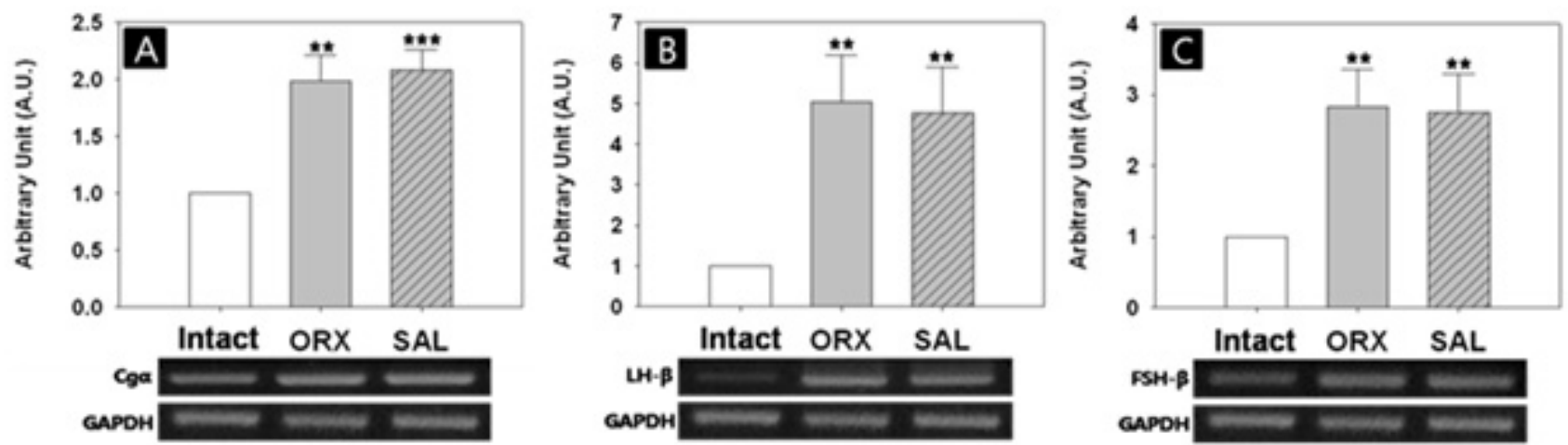

Fig. 2. Effects of ORX or hypertonic saline BITI on changes in pituitary hormone gene expression. After 4 weeks of surgery or saline injection, total RNAs were extracted from the pituitaries and then used in preparation of cDNAs. Semi-quantitative RT-PCRs were performed using gene-specific primers under the specific conditions (Table 1 \& 2). The bar indicates the mean value $( \pm$ S.E.) of the repeated experiment $(n=6-8)$. Statistical differences were analyzed by Student's $t$-test. Significantly different from the intact group, $p<0.01$. ***, Significantly different from the intact group, $p<0.001$.
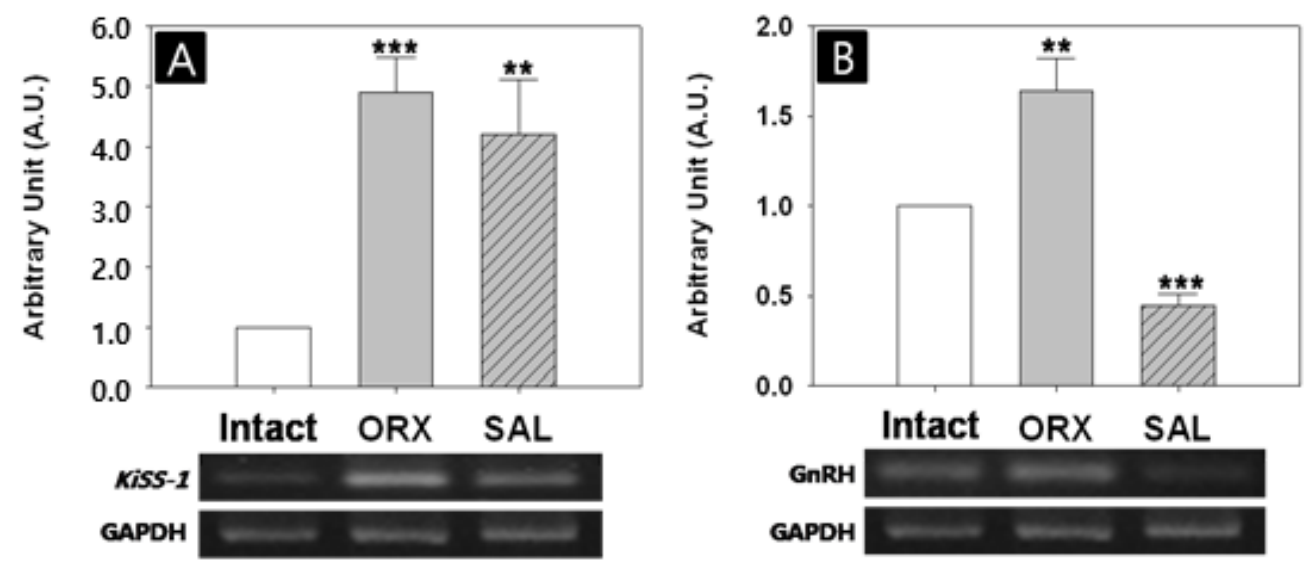

Fig. 3. Effects of ORX or hypertonic saline BITI on changes in hypothalamic hormone gene expression. After 4 weeks of surgery or saline injection, total RNAs were extracted from the hypothalami and then used in preparation of cDNAs. Semi-quantitative RT-PCRs were performed using gene-specific primers under the specific conditions (Table $1 \& 2)$. The bar indicates the mean value $( \pm$ S.E. $)$ of the repeated experiment $(n=6-8)$. Statistical differences were analyzed by Student's $t$-test. *, Significantly different from the intact group, $p<0.05$. **, Significantly different from the intact group, $p<0.01$. ***, Significantly different from the intact group, $p<0.001$.

effects of the two castration methods on the hormone expressions of pituitary and hypothalamus at transcriptional level. To confirm whether the androgen deprivation occurred sufficiently, we measured the serum $\mathrm{T}$ levels of the two groups. The serum $\mathrm{T}$ levels were dramatically decreased in both ORX group and hypertonic saline injection group after 4 weeks of the manipulations. The suppression rates, less than $1 / 6$ of intact level, were similar in the two groups. This finding was in good agreement with previous studies, showing complete ablation of Leydig cell populations in the testis of hypertonic saline- or calcium chloridetreated rats (Jana et al., 2002; Emir et al., 2008). 
Concerning the injection materials used in simple chemical castration methods, the use of calcium chloride anteceded that of sodium chloride. In rats, serum $\mathrm{T}$ level was dramatically reduced after 4 weeks post-injection in a dosedependent manner $(5-20 \mathrm{mg} /$ testis $/ 100 \mathrm{~g}$ body wt in $0.1 \mathrm{~mL}$ saline) by single calcium chloride BITI (Jana et al., 2002). The authors also demonstrated similar dose-dependent (5$20 \mathrm{mg} /$ testis/ $\mathrm{kg}$ body wt in $1 \mathrm{~mL}$ saline) decrease of serum $\mathrm{T}$ level in dogs after 45 days post-injection (Jana \& Samanta, 2007). In contrast, chemical castration with $20 \%$ calcium chloride injection into donkey testes failed to induce marked decrease in serum T; only $45 \%$ of initial serum level after 1 month post-injection, and the histopathological study confirmed the presence of proliferative Leydig cells (Ibrahim et al., 2016). These results suggest that the castration effect of calcium chloride injection may vary depending on the species. Previous study and our present result demonstrate both calcium chloride and sodium chloride could have similar capability of androgen deprivation in rats, when the same hypertonic condition $(20 \%)$ was applied (Jana et al., 2002). It is intriguing that BITI of $20 \%$ calcium chloride in $95 \%$ ethanol as diluent instead of saline or lidocaine revealed improved sterilization and $\mathrm{T}$ deprivation in dogs (Leoci et al., 2014).

It is well known that gonadal steroids exert direct negative feedback effects at the pituitary as well as at the hypothalamic level in rodents (Kalra \& Kalra, 1983). In male rats, ORX can cause an increase in serum LH concentrations, and $\mathrm{T}$ replacement can suppress these levels (Kalra, 1985). ORX also induces the changes in transcriptional levels of pituitary and hypothalamic hormones. In the present study, both ORX and hypertonic saline injection significantly increased mRNA levels of pituitary $\mathrm{Cg} \alpha, \mathrm{LH}-\beta$ and FSH- $\beta$ by similar extents. Likewise, hypothalamic KiSS-1 mRNA levels were significantly increased by the two castration procedures. These findings are in line with the ORX effects on expressions of gonadotropin subunits and KiSS-1 in previous studies (Dalkin et al., 2001; Castel- lano et al., 2009), and indicates the two procedures could have equivalent potential in the regulation of the hormone gene expressions. However, changes in hypothalamic GnRH mRNA levels in response to the two castration procedures are opposite in our study; significant increase in ORX group and significant decrease in hypertonic saline injection group. Indeed, effects of ORX on the hypothalamic GnRH expression in male rats have been disputable issue. As a consequence of ORX, GnRH mRNA levels are either unchanged (Wiemann et al., 1990) or decreased (Rothfeld et al., 1987) in male rats. Making things more complicated, recent study reported that ORX elevates hypothalamic GnRH expression (Spratt \& Herbison, 1997), and this result coincides with our finding. On the other hand, our hypertonic saline injection study disclosed significant decline in GnRH mRNA. We speculate about plausible causes for this huge discrepancy in hypothalamic GnRH expression between ORX group and hypertonic saline injection group. First, the levels of hypothalamic GnRH transcript seem to be fluctuated after androgen deprivation (Emanuele et al., 1996), and the expression profiles could be temporally different between these two groups. Second, unlike in ORX animals, relatively high level of phagocytosis will be maintained for some period in the testes of chemically castrated animals. This pathophysiological state will carry over the systemic elevation in inflammatory cytokine and corticosterone which can play as modulators of hypothalamic GnRH expression (Wu \& Wolfe, 2012; Gore et al., 2006). Third, some reports insist the presence of 'direct neural pathway between the hypothalamus and the testes' that modulates $\mathrm{T}$ secretion independently of the pituitary (Selvage \& Rivier, 2003; Selvage et al., 2006; James et al., 2008). The degree of this testicular denervation could be different between the two castration procedures, expecting 'instant full denervation' in ORX animals while 'delayed full denervation' in hypertonic saline injection group. This temporal gap may cause the differential expressions of hypothalamic genes in the two 
groups. Further studies, allowing these aspects, are necessary in order to evaluate the hypertonic saline BITI method as a substitute for ORX in preparation of animal model for investigating the androgen effects on the hypothalamic target gene expressions.

Growing number of evidence shows that chemical castrations by BITI of simple salt solution have arrived at a reliable sterilization method for rat, dog and cattle (Jana \& Samanta, 2006; Jana \& Samanta, 2007; Fagundes et al., 2014; Neto et al., 2014). Astonishingly, no scientific trial has been undertaken into the androgen deprivation potential of this simple chemical castration method as a substitute for ORX in biomedical researches. Actually, numerous studies have employed 'ORX and/or $\mathrm{T}$ replacement animal model' to clarify the physiological roles of androgen (Valenti et al., 1997; Lightfoot, 2008; Inada et al., 2011). Nonetheless, chemical castrations by BITI of simple salt solution could have certain advantages over surgical castration. Surgical castration is a time- and cost-consuming procedure, should be performed by experts, and it also imposes burdens on animals with unhealthy conditions. During and after the surgery, the animals could be improperly damaged by anesthesia and unexpected infection. Furthermore, the surgical procedure itself tends to be an animal welfare violation. Our study revealed there were no detectable changes in the general health status of the hypertonic saline-injected animals with the exception of testicular atrophy, and daily consumption of food and water remained unaffected. So minimum safety of hypertonic saline BITI method could be guaranteed.

We previously demonstrated that hypertonic saline BITI can induce ORX-like $\mathrm{T}$ deprivation effects on accessory sex organs such as weight loss of the epididymis, and identical protein patterns on SDS-PAGE (Kwak \& Lee, 2013). Taken together, despite the lack of available strong evidence-based data on the mechanisms of the testicular cell death and $\mathrm{T}$ deprivation, the present study suggests the chemical castration by hypertonic saline BITI could be a promising substitute to conventional surgical castration. Effort to improve the safety and efficiency as well as extension of target tissue coverage of the chemical castration with simple salt solution will be worth in near future, particularly in biomedical researches.

\section{ACKNOWLEDGEMENTS}

This research was supported by a 2013 Research Grant from Sangmyung University.

\section{REFERENCES}

Attar RM, Takimoto CH, Gottardis MM (2009) Castrationresistant prostate cancer: locking up the molecular escape routes. Clin Cancer Res 15:3251-3255.

Castellano JM, Navarro VM, Roa J, Pineda R, SánchezGarrido MA, García-Galiano D, Vigo E, Dieguez C, Aguilar E, Pinilla L, Tena-Sempere M (2009) Alterations in hypothalamic KiSS-1 system in experimental diabetes: early changes and functional consequences. Endocrinology 150:784-794.

Costantino A, Gava G, Berra M, Meriggiola MC (2014) Advances in male hormonal contraception. Indian $\mathrm{J}$ Med Res 140 Suppl:S58-62.

Dalkin AC, Burger LL, Aylor KW, Haisenleder DJ, Workman LJ, Cho S, Marshall JC (2001) Regulation of gonadotropin subunit gene transcription by gonadotropinreleasing hormone: measurement of primary transcript ribonucleic acids by quantitative reverse transcriptionpolymerase chain reaction assays. Endocrinology 142: 139-146.

Durán-Pastén ML, Fiordelisio-Coll T, Hernández-Cruz A (2013) Castration-induced modifications of GnRHelicited $\left[\mathrm{Ca}^{2+}\right]_{\mathrm{i}}$ signaling patterns in male mouse pituitary gonadotrophs in situ: Studies in the acute pituitary slice preparation. Biol Reprod 88:1-11.

Emanuele NV, Jurgens J, La Paglia N, Williams DW, Kel- 
ley MR (1996) The effect of castration on steady state levels of luteinizing hormone-releasing hormone (LHRH) mRNA and proLHRH processing: Time course study utilizing semi-quantitative reverse transcription/polymerase chain reaction. J Endocrinol 148:509-515.

Emir L, Dadali M, Sunay M, Erol D, Caydere M, Ustü H (2008) Chemical castration with intratesticular injection of $20 \%$ hypertonic saline: A minimally invasive method. Urol Oncol 26:392-396.

Emir L, Sunay M, YalbuzdağO, Karakaya Y, Erol D (2011) Hormonal and pathologic changes after chemoablation of testes with hypertonic saline solution as a treatment method alternative to orchiectomy in patients with hormone sensitive metastatic prostatic cancer. Urol Oncol 29:212-217.

Fagundes AK, Oliveira EC, Tenorio BM, Melo CC, Nery LT, Santos FA, Alves LC, Douglas RH, Silva VA Jr (2014) Injection of a chemical castration agent, zinc gluconate, into the testes of cats results in the impairment of spermatogenesis: A potentially irreversible contraceptive approach for this species? Theriogenology $81: 230-236$.

Fordyce G, Hodge PB, Beaman NJ, Laing AR, Campero C, Shepherd RK (1989) An evaluation of calf castration by intra-testicular injection of a lactic acid solution. Aust Vet J 66:272-276.

Gore AC, Attardi B, DeFranco DB (2006) Glucocorticoid repression of the reproductive axis: Effects on GnRH and gonadotropin subunit mRNA levels. Mol Cell Endocrinol 256:40-48.

Ibrahim A, Ali MM, Abou-Khalil NS, Ali MF (2016) Evaluation of chemical castration with calcium chloride versus surgical castration in donkeys: testosterone as an endpoint marker. BMC Vet Res 12:46

Inada M, Matsumoto C, Miyaura C (2011) Animal models for bone and joint disease. Ovariectomized and orchidectomized animals. Clin Calcium 21:164-170.

James P, Rivier C, Lee S (2008) Presence of corticotro- phin-releasing factor and/or tyrosine hydroxylase in cells of a neural brain-testicular pathway that are labelled by a transganglionic tracer. J Neuroendocrinol 20:173-181.

Jana K, Samanta PK (2006) Evaluation of single intratesticular injection of calcium chloride for nonsurgical sterilization in adult albino rats. Contraception 73:289300.

Jana K, Samanta PK (2007) Sterilization of male stray dogs with a single intratesticular injection of calcium chloride: A dose-dependent study. Contraception 75:390400.

Jana K, Samanta PK, Ghosh D (2002) Dose-dependent response to an intratesticular injection of calcium chloride for induction of chemosterilization in adult albino rats. Vet Res Commun 26:651-673.

Jung MJ, Moon YC, Cho IH, Yeh JY, Kim SE, Chang WS, Park SY, Song CS, Kim HY, Park KK, McOrist S, Choi IS, Lee JB (2005) Induction of castration by immunization of male dogs with recombinant gonadotropin releasing hormone (GnRH)-canine distemper virus (CDV) T helper cell epitope p35. J Vet Sci 6:21-24.

Kalra PS (1985) Further studies on the effects of testosterone on hypothalamic LH-RH and serum LH levels: castration-induced delayed response. Neuroendocrinology 41:219-223.

Kalra SP, Kalra PS (1983) Neural regulation of luteinizing hormone secretion in the rat. Endocr Rev 4:311-351.

Kwak BK, Lee S-H (2013) Intratesticular injection of hypertonic saline; non-invasive alternative method for animal castration model. Dev Reprod 17:435-440.

Leoci R, Aiudi G, Silvestre F, Lissner EA, Lacalandra GM (2014) Alcohol diluent provides the optimal formulation for calcium chloride non-surgical sterilization in dogs. Acta Vet Scand 14;56-62.

Lightfoot JT (2008) Sex hormones' regulation of rodent physical activity: A review. Int J Biol Sci 4:126-132.

Neto OA, Gasperin BG, Rovani MT, Ilha GF, Nóbrega JE 
Jr, Mondadori RG, Gonçalves PB, Antoniazzi AQ (2014)

Intratesticular hypertonic sodium chloride solution treatment as a method of chemical castration in cattle. Theriogenology 82:1007-1011.

Rhodes L (2017) New approaches to non-surgical sterilization for dogs and cats: Opportunities and challenges. Reprod Domest Anim 52 Suppl 2:327-331.

Rothfeld JM, Hejtmancik JF, Conn PM, Pfaff DW (1987) LHRH messenger RNA in neurons in the intact and castrate male rat forebrain, studied by in situ hybridization. Exp Brain Res 67:113-118.

Selvage DJ, Parsons L, Rivier C (2006) Role played by brainstem neurons in regulating testosterone secretion via a direct neural pathway between the hypothalamus and the testes. Endocrinology 147:3070-3075.

Selvage DJ, Rivier C (2003) Importance of the paraventricular nucleus of the hypothalamus as a component of a neural pathway between the brain and the testes that modulates testosterone secretion independently of the pituitary. Endocrinology 144:594-598.

Smith JT, Dungan HM, Stoll EA, Gottsch ML, Braun RE, Eacker SM, Clifton DK, Steiner RA (2005) Differential regulation of KiSS-1 mRNA expression by sex steroids in the brain of the male mouse. Endocrinology 146:
2976-2984.

Spratt DP, Herbison AE (1997) Regulation of preoptic area gonadotrophin-releasing hormone $(\mathrm{GnRH}) \mathrm{mRNA}$ expression by gonadal steroids in the long-term gonadectomized male rat. Brain Res Mol Brain Res 47:125-133.

Valenti S, Sarkissian A, Giusti M, Giordano G, Dahl KD (1997) Immunoreactive and bioactive LH release from pituitaries of intact or castrated male rats: effect of in vitro $\mathrm{GnRH}$ and $\mathrm{KCl}$ administration. J Endocrinol Invest 20:381-386.

Wiebe JP, Barr KJ (1984) The control of male fertility by 1,2,3-trihydroxypropan (THP; glycerol): rapid arrest of spermatogenesis without altering libido, accessory organs, gonadal steroidogenesis and serum testosterone. LH and FSH. Contraception 29:291-302.

Wiemann JN, Clifton DK, Steiner RA (1990) Gonadotropin-releasing hormone messenger ribonucleic acid levels are unaltered with changes in the gonadal hormone milieu of the adult male rat. Endocrinology 127:523532.

Wu S, Wolfe A (2012) Signaling of cytokines is important in regulation of GnRH neurons. Mol Neurobiol 45:119125. 